\title{
The Role of the Balanced Scorecard on Performance: Case Study of the Housing Bank for Trade and Finance
}

\author{
Sakhr Bani Khaled ${ }^{1} \&$ Audeh Bani-Ahmad ${ }^{1}$ \\ ${ }^{1}$ Faculty of Economics and Administrative Sciences, Al al-Bayt University, Jordan \\ Correspondence: Sakhr Bani Khaled, Researcher, Master's Degree of Accounting, Jordan. Email: \\ sakhr87@gmail.com
}

Received: November 19, 2018

Accepted: December 17, 2018 Online Published: December 30, 2018

doi:10.5539/ijef.v11n2p17

URL: https://doi.org/10.5539/ijef.v11n2p17

\begin{abstract}
This study aimed at identifying the extent of the use of the balanced scorecard in the Housing Bank for Trade and Finance, as was laid out in the Bank's plans. Therefore, employee and customer surveys were conducted to study both the internal Perspectives of operations, growth, and learning, and to measure customer satisfaction with the bank's services. The study also conducted an analysis of the financial performance compared to the index of the industry related to the Jordanian banks. After analyzing the data and hypotheses, the study found that the use of the balanced scorecard came in line with its strategic plans, and the financial performance of the bank was superior to the banking sector. The study recommends an increased use of balanced scorecards in order to sustain customer satisfaction.
\end{abstract}

Keywords: balanced scorecard, the housing bank of trade and finance, strategy, performance

\section{Introduction}

In the middle of the rapid changes experienced by the world in which we are trying to live with it as much as possible, and where the information contributed to a quick acceleration in the rashness of decision-making, it became necessary to see where we are from the availability of information in a way that helps decision-making and contributes in increasing the rates of transparency and achieving the equality and justice, in addition to the continuation of the development projects, maintain and increase their rates.

Furthermore, the environmental variables surrounding the accounting system in general and management accounting, especially of the increased global competition and the huge technological developments and the information revolution that has increased the administrative need to strategic information relating to the external environment and analyses of the competitor, on the other hand, a deficit in the traditional methods of accounting management appeared in the field of planning, control and performance assessment, which led to the need to develop new methods of measuring such as the customer satisfaction and the ability to maintain the customer and staff satisfaction and their skills by virtue of that financial measures alone are insufficient to guide and assess the facilities' work.

Hence this study appeared to show the role of using the Balanced Scorecard in the performance assessment of the Housing Bank for Trade and Finance.

\section{Study Problem}

The study problem is determined whether the financial and administrative staff existing in the Housing Bank is able to deal with the Balanced Scorecard as a method of advanced management accounting methods and submit it in the desired image model or if the elements of the accounting system still need to be developed to be able to deal with the Balanced Scorecard model as a mean to assess the performance, both financial and administrative, and to balance the indicators and performance standards, the problem of the study will answer the following question:

Is there a role for the Balanced Scorecard on the performance in Housing Bank for Trade and Finance?

\section{Objectives of the Study}

This study aims to determine the most important terms related to the Balanced Scorecard and measurement of financial performance and demonstrate the related advantages as a result of the criticisms directed to the 
traditional management accounting systems, which the most important represented in: Providing inadequate information to decision makers, lack of attention to the requirements of today's entities and their strategies, Taking care of short-term planning, the inability to provide clear and honest image, providing a misleading information regarding the allocation of costs and control over investments and providing abstract information for employees, lack of attention to the work environment and focus on the short-term foreseeable (Nils, Jean, \& Mayer, 2003) and this what Kaplan and Norton had proposed to reflect a balance between short and long-term goals, as well as to financial and non-financial standards and between the leadership or follow the phenomena and changes and between external and internal performance standards perspectives.

\section{The Significance of the Study}

The significance of the study emerged from the urgent need to assess the performance of organizations and to provide decision-makers with relevant information that reinforces the process of improving the economic level of the organization, which will reflect positively on the financial performance, this is what it is supposed to achieve by the Balanced Scorecard as it uses the non-financial information that the traditional systems ignored it significantly, which enhances the ability of Housing Bank in measuring the strategic and operational performance, so that it can cope with competitors in the domestic and external market, that the bank has no branches outside the borders of the Hashemite Kingdom of Jordan.

\section{Hypotheses of the Study}

The First Null Hypothesis:

H01: There is no statistically significant difference at a significance level of $(\alpha \leq 0.05)$ of the arithmetic mean of the financial ratios with the average standard ratios for commercial banks sector.

\section{The Second Null Hypothesis:}

H02: There is a low statistically significant role at the level of significance of $(\alpha \leq 0.05)$ to customers' use aspect of the Balanced Scorecard in the Housing Bank for Trade and Finance.

\section{The Third Null Hypothesis:}

H03: There is a low statistically significant role at a significance level of $(\alpha \leq 0.05)$ to internal processes use aspect on the Balanced Scorecard in the Housing Bank for Trade and Finance.

\section{The Fourth Null Hypothesis:}

H04: There is a low statistically significant role at a significance level of $(\alpha \leq 0.05)$ to the learning and growth using aspect on the Balanced Scorecard in the Housing Bank for Trade and Finance.

\section{The Theoretical Literature}

Many modern studies have dealt with the Balanced Scorecard and many aspects of its application, In their study, Al-Mahamid and Al-Sulaihat, they aimed to measure the impact of practising of knowledge management process in performance using the assessment of Balanced Scorecard in small and medium-sized industrial companies, there is an impact in the practice of knowledge management in using indicators regarding the internal processes as a dimension of the balanced scorecard. application (Al-Mahamid \& Al-Sulaihat, 2013)

There is also an effect of the practice of knowledge management in using indicators relating to the internal operations as a dimension of the assessment of balanced performance card, as well as the presence of an impact for the practice of knowledge management in using the indicators with respect to customers as a dimension of the assessment of balanced performance card.

In a study of (Al-Natour, 2005), the results have emerged on the basis of statistical analysis of the data on the usefulness of using the Balanced Scorecard as a comprehensive tool of financial and non-financial standards to assess the performance to improve the industrial establishment strategy and improvement of investment decision and thus achieve objectivity in advanced projects technology, in addition to the benefit of the Balanced Scorecard as a tool to increase the effectiveness of project management through the financial performance development, this has been confirmed by (Al-Harbi, 2007), (Michalsk, 2005), while (Soderberg, 2006) developed the Balanced Scorecard model based on the performance characteristics proposed from (Kaplan and Norton's balanced scorecard, 1992, 1996, 2001).

The model was applied to a sample of Canadian companies with more than 51 employees. The study concluded that $37.8 \%$ of companies used the Balanced Scorecard while $62.2 \%$ of the companies did not use the Balanced Scorecard.

In another aspect, the study of Benedetta \& Maura addressed the Balanced Scorecard methodology and its ability 
to improve the measurement and assessment of the performance of human resources in the public sector in the United States (Benedetta \& Maura, 2015).

In their study, Pollanen and Xi examined how the use of Balanced Scorecard (BSC) measures in executive compensation affected organizational performance. The study found a correlation with both the effectiveness and efficiency dimensions of performance (Pollanen \& Xi, 2018). Gomes and Liddle aimed to promote the theory of public management by presenting empirical evidence of using Balanced Scorecard for third sector organizations. The study findings indicate that developing a single Balanced Scorecard for each department promotes cooperation rather than competition and leads to synergy rather than fragmentation (Gomes \& Liddle, 2009).

In 2009, (De Geuser, Mooraj, \& Oyon) investigated the effect of BSC on organizational performance, building on survey data collected from 76 business units (De Geuser et al., 2009). The results showed a positive impact on performance. In addition, the study showed that BSC improves integration of management processes and empowers people. Using the Strategy-Focused-Organization (SFO) model, Kaplan and Norton showed that the sources of performance derived from BSC are of three types:(1) the fact that strategizing becomes a continuous process, (2) the greater alignment of various processes, services, competencies and units of an organization, and (3) a better translation of the strategy into operational terms (Kaplan \& Norton, 2001).

A further study aimed to explore the relationship between Judging divisional performance using the balanced scorecard is a complex task. They demonstrate that when strategy information is provided to managers and only some measures are strategically linked, the common measures bias exists (consistent with Banker, Chang, \& Pizzini, 2004). However, if strategy information is provided and all measures are strategically linked, the common measures bias is eliminated (Humphreys \& Trotman, 2011).

In addition, Lucianetti investigated adoption experience amongst organizations in connection with the strategy map design. Using survey data from managers of 91 Italian organizations the paper seeks to verify whether the development of the strategy maps affects BSC performance and in turn business results. Evidence shows that benefits coming from BSC usage are considerably lower for those organizations who have not implemented this model in connection with the design of an appropriate strategy map. The implications for managers appears very interesting given that the lack of development of strategy maps related to the BSC model seems to not only substantially decrease its perceived expected benefits, but also decreases the organization's overall competitiveness (Lucianetti, 2010).

A further study investigated whether bank branches implementing the Balanced Scorecard outperform bank branches within the same banking organization on key financial measures. Although the BSC has gained popularity among managers as a performance measurement tool, little empirical evidence exists to substantiate claims that the BSC promotes superior financial performance when compared to a traditional performance measurement system. We find evidence of superior financial performance for branches implementing the BSC when compared to non-BSC implementing branches (Davis \& Albright, 2004).

In addition, Braam \& Nijssen's study aims to explore how the way in which the BSC is used affects performance. Empirical evidence from Dutch firms suggests BSC use will not automatically improve company performance, but that this depends on the manner of its use matters: BSC use aligned with corporate strategy positively will improve company performance, while BSC use that is not related to the strategy may decrease it (Braam \& Nijssen, 2004).

On the other hand, the study of Northcott \& Ma'amora Taulapapa examines the use of the balanced scorecard as a performance management tool in the public sector. Drawing on a New Zealand study of local government organizations (LGOs), it seeks to identify issues and challenges in implementing the BSC in public sector contexts. The study findings revealed low rates of BSC adoption amongst the studied LGOs. Further, perceived BSC utility is dominated by performance measurement and reporting, while the performance management role of the BSC remains relatively under-exploited. (Northcott \& Ma'amora Taulapapa, 2012).

\subsection{The Concept of the Balanced Scorecard}

In 1992 Robert S. Kaplan and David P. Norton presented -through the publication of an article in the Harvard journal for business the concept of Balanced Scorecard to measure the organization's activities and motives of work compared to its objectives by linking them to the vision and strategy of the organization, this is done by focusing on the financial and non-financial aspects of the organization specifically and to focus on the human element and a long-term concerns in a strategic vision, which is based on improving performance through balancing financial objectives with customers, internal processes, personnel and measuring future performance.

The Balanced Scorecard proposes to take a look on the organization during four dimensions (areas) for the 
development of performance depending on this matrix in data collection and its analysis interconnected with each other, these areas are:

\section{first: Financial Process Perspective:}

Financial objectives are an important component of the Strategy Map, in the for-profit, public, and nonprofit worlds. In the for-profit domain, the objectives in this perspective represent the end in mind of our strategic story, typically culminating in objectives such as "Increase shareholder value" "Grow revenues" and "Lower costs". (Niven, 2011, p. 18).

Therefore this perspective reflects the past operating performance of a company including the achievement of setting up a financial target and the implementation of executing strategies. In spite of this, it could be seen whether organizations gain growth, return and risk control from operating strategies. The indices of evaluation usually contain operating income, operating costs, return on investment, net profit rate, cash flows, and so forth (Ardekani et al., 2013, p. 84).

\section{Second: Customer Process Perspective:}

When choosing measures for the Customer perspective of the Balanced Scorecard, organizations must answer two critical questions: "Who are our target customers?" and "What is our value proposition in serving them?" Sounds simple enough, but both of these questions offer many challenges to organizations. Most organizations will state that they do in fact have a target customer audience, yet their actions (Niven, 2005, p. 13)

This is a strategy for creating value and differentiation from the perspective of the customer. The managers are obligated to produce measures to respond to the following question: "To achieve our vision, how should we appear to our customers?" Distinctive measures used under this perspective are: customer satisfaction, customer complaints, customer lost/won, sales from a new product (Panicker \& Seshadri, 2013, p. 64).

\section{Third: Internal Business Process Perspective:}

This perspective includes an internal business process to ensure the highest possible quality of products and services. The firms' products and services must meet the market requirement, both in quantity and quality. The key performance indicators are process improvements, supply chain management (Dan, 2017, p. 8).

\section{Fourth: Learning \& Growth Process Perspective:}

Learning \& Growth Perspective focuses on the intangible assets of an organization, mainly on the internal skills and capabilities of the employees that are required to support the value-creating internal processes. The Learning \& Growth Perspective focuses on Human, Information \& Organization Capital. The Learning and Growth objectives describe how the people, technology, and organizational climate combine to support strategy. Measures in this perspective are lead indicators for improvements in the internal processes, customer and financial perspectives (Narayanamma \& Lalitha, 2016, p. 62).

\subsection{Definition of Performance Assessment}

The performance assessment is A periodic process aimed at measuring the strengths and weaknesses in the efforts of workers and behaviors that they practice in a certain position planned previously by the organization (Shawqi, 2005, p. 75).

Performance assessment defines as "Measure process and a description of the behavior of the worker and its achievements during a specified period, in order to improve performance" (Riks, 1995, p. 250), it is noted from the above definitions that performance assessment programs are seeking to achieve two goals: Administrative Goal: By taking the necessary decisions in the light of the results obtained. Developmental Purpose: By identifying weaknesses and work to overcome them.

Performance assessment benefits directly in diagnose problems and solve them to acknowledge the strengths and weaknesses of the entity, it also serves in providing management with the necessary information to the public decision-making, both for investment and development, or when making significant changes, such as the purchase of equipment, products change, the invasion of new markets, it is one of the most important pillars of policy-making, both at the entity's level or at the industry level or at the state level.

\section{Population and Study Sample}

Considering that the study is a case study, the population study is represented in Housing Bank for Trade and Finance, where its financial statements have been published for the year (2014) and were subjected to study in order to assess one aspect of the Balanced Scorecard, which is the financial process, in addition to the bank's customers to cover the side of customer satisfaction and the bank staff to cover the side of the internal processes 
by distributing the study tool on them.

\section{Statistical Analysis}

Table 1. Cronbach's alpha coefficient in the areas of study and tool as a whole

\begin{tabular}{cccc}
\hline No. & Area & Paragraph No. & Cronbach's alpha coefficient \\
\hline 1 & Internal Business Process (staff) & 8 & 0.83 \\
2 & Learning and growth Process (staff) & 8 & 0.85 \\
3 & Customer Process (customer satisfaction) & 17 & 0.84 \\
\hline
\end{tabular}

Note. Prepared by the researchers upon the results of a statistical analysis.

It is shown from Table 1 that the Cronbach's alpha coefficients for the fields of study ranged between (0.83-0.85), where the field of "Learning and Growth Process" reached (0.85), and for the field of "Internal Business Processes" reached (0.83), and the field of "Customer Process" reached (0.84) and all the reliability coefficients are high and acceptable for the purposes of the study, where the reliability coefficient (Cronbach's alpha) is acceptable if exceeded (0.70). (Sekaran \& Bougie,2016).

\subsection{Descriptive Statistics}

\subsubsection{First Area: Financial Process Perspective}

Table 2. The results of financial performance are measured by financial ratios and standard values

\begin{tabular}{|c|c|c|c|}
\hline Financial Ratios & $\begin{array}{l}\text { Value percentage } \\
\text { in } 2014 \text { for the } \\
\text { Housing Bank }\end{array}$ & $\begin{array}{l}\text { Industry Index } \\
\text { for Jordanian } \\
\text { Banks }\end{array}$ & Evaluation \\
\hline $\begin{array}{l}\text { Return on Assets } \\
\quad \text { Ratio }\end{array}$ & $1.63 \%$ & $1.38 \%$ & $\begin{array}{l}\text { The ratio was higher than the industry index and this shows that the bank } \\
\text { has the ability to generate profits excellently. }\end{array}$ \\
\hline $\begin{array}{l}\text { Return on Equity } \\
\quad \text { Ratio }\end{array}$ & $11.93 \%$ & $9.68 \%$ & $\begin{array}{l}\text { The ratio was higher than the industry index with the knowledge that } \\
\text { property rights were one of the top banks in Jordan, which is a good sign. }\end{array}$ \\
\hline Dupont Model & $2.134 \%$ & $1.908 \%$ & $\begin{array}{l}\text { The ratio was higher than the standard, which means that the bank is the } \\
\text { best and has the ability to generate profits from operating assets. }\end{array}$ \\
\hline $\begin{array}{l}\text { Debt-Equity } \\
\quad \text { Ratio }\end{array}$ & $631.41 \%$ & $597 \%$ & $\begin{array}{l}\text { The ratio was higher than the standard which indicates that the total } \\
\text { liabilities are greater than the total property rights ratio, but it is considered } \\
\text { normal compared with the banking sector. }\end{array}$ \\
\hline Debt Ratio & $86 \%$ & $85 \%$ & $\begin{array}{l}\text { The ratio was very close to its standard and indicates that the bank has the } \\
\text { ability to repay the debt, where it constitutes } 86 \% \text { of assets. }\end{array}$ \\
\hline
\end{tabular}

Note. Prepared by the researchers upon the results of a statistical analysis.

\subsubsection{Second Area: Customer Process Perspective (Customer Satisfaction)}

Table 3. Mean and standard deviation of the area paragraphs of "customer satisfaction"

\begin{tabular}{|c|c|c|c|c|c|}
\hline No. & Paragraph & Mean & Standard Deviation & Rank & Degree \\
\hline 1 & The Bank communicates with customers and its ability to keep them. & 4.13 & 0.72 & 7 & High \\
\hline 2 & The Bank performs transactions in a very short period. & 4.00 & 0.75 & 13 & High \\
\hline 3 & The employee, who is in his workplace and is familiar with the nature of his work. & 4.13 & 0.69 & 7 & High \\
\hline 4 & The Bank provides waiting for seats in the customer service centres. & 4.40 & 0.63 & 1 & High \\
\hline 5 & $\begin{array}{l}\text { The transactions are completed in the bank in an accurate, easy and simplified } \\
\text { manner. }\end{array}$ & 4.28 & 0.68 & 3 & High \\
\hline 6 & The employee deals with customers in courtesy and friendly manner. & 3.95 & 0.75 & 14 & High \\
\hline 7 & The Employee enjoys transparency in dealing with customers. & 3.83 & 0.81 & 17 & High \\
\hline 8 & $\begin{array}{l}\text { The Bank provides electronic services commensurate with customer segments } \\
\text { (Bank services on smartphones, online banking and ATMs). }\end{array}$ & 4.03 & 0.77 & 12 & High \\
\hline 9 & $\begin{array}{l}\text { The Bank offers modern ATMs distributed in various regions of the Hashemite } \\
\text { Kingdom of Jordan. }\end{array}$ & 3.90 & 0.78 & 15 & High \\
\hline 10 & $\begin{array}{l}\text { The Bank provides multiple branches in different regions of the Hashemite } \\
\text { Kingdom of Jordan. }\end{array}$ & 3.90 & 0.81 & 15 & High \\
\hline 11 & The Bank provides mobile branches to serve customers and their needs. & 4.10 & 0.84 & 10 & High \\
\hline
\end{tabular}




\begin{tabular}{rlrccc}
\hline 12 & The Bank provides a variety of awards for savings accounts and other accounts. & 4.18 & 0.78 & 6 & High \\
13 & The Bank provides a variety of e-cards in addition to providing support to its high & 4.20 & 0.76 & 5 & High \\
& protection. & 4.13 & 0.79 & 7 & High \\
14 & The Bank cares about the quality of provided service to customers. & 4.40 & 0.78 & 1 & High \\
15 & The Bank enhances social responsibility in the local community. & 4.28 & 0.75 & 3 & High \\
16 & The Bank manages customer complaints quickly and taken them seriously. & 4.10 & 0.71 & 10 & High \\
\hline & The Bank communicates with customers through social network sites. & 4.11 & 0.32 & - & High \\
\hline
\end{tabular}

Note. Prepared by the researchers upon the results of a statistical analysis.

It is shown in the Table 3 that the arithmetic mean of the field paragraphs of "Customer Satisfaction" ranged between (3.83-4.40), the highest paragraphs were $(4 \& 15)$, which states that "The Bank provides waiting for seats in the customer service centers.", "The Bank enhances the social responsibility in the local community". And the last rank was paragraph (7), which states "The Employee enjoys transparency in dealing with customers.", with a mean of (3.83) and in a high degree and the arithmetic means of the area of "Customer Satisfaction" reached as a whole (4.11) and in a high degree.

\subsubsection{Third Area: Internal Business Process Perspective (Staff)}

Table 4. The mean and standard deviation of the "internal processes field" paragraphs and the area as a whole

\begin{tabular}{|c|c|c|c|c|c|}
\hline No. & Paragraph & Mean & Standard deviation & Rank & Degree \\
\hline 1 & The Bank reviews the procedures for granting credit. & 4.50 & 0.52 & 2 & High \\
\hline 2 & $\begin{array}{l}\text { The Bank applies the rules and regulations that ensure the safety of credit } \\
\text { decision. }\end{array}$ & 4.17 & 0.39 & 8 & High \\
\hline 3 & $\begin{array}{l}\text { The Bank develops technological infrastructure and increases the efficiency of } \\
\text { their use in various aspects of work in the bank. }\end{array}$ & 4.42 & 0.51 & 6 & High \\
\hline 4 & $\begin{array}{l}\text { The Bank strengthens the efficiency of electronic channels and direct clients } \\
\text { towards the use of alternative channels such as bank services applications on } \\
\text { smartphones and banking internet and bank ATMs. }\end{array}$ & 4.42 & 0.51 & 6 & High \\
\hline 5 & $\begin{array}{l}\text { The Bank strengthens the network of branches in areas that prove the feasibility of } \\
\text { the branching. }\end{array}$ & 4.50 & 0.52 & 2 & High \\
\hline 6 & The Bank improves the overall appearance of the existing branches. & 4.50 & 0.52 & 2 & High \\
\hline 7 & $\begin{array}{l}\text { The Bank strengthens the network of ATMs and maintains the continuity of its } \\
\text { work efficiently. }\end{array}$ & 4.75 & 0.45 & 1 & High \\
\hline 8 & $\begin{array}{l}\text { The Bank strengthens the capacities and potential of foreign branches and } \\
\text { subsidiaries. }\end{array}$ & 4.50 & 0.52 & 2 & High \\
\hline & "Internal processes" as a whole & 4.47 & 0.26 & - & High \\
\hline
\end{tabular}

Note. Prepared by the researchers upon the results of a statistical analysis.

It is shown in the Table 4 that the arithmetic mean of the "Internal Processes" field ranged between (4.17-4.75), the highest was of the paragraph (7) with a mean of (4.75) and with a high degree and the last rank was paragraph (2) which states that "The Bank applies the rules and regulations that ensure the safety of credit decision." with a mean of (4.17) and in a high degree and the arithmetic means of the field of "Internal Processes" reached as a whole (4.47) and in a high degree.

\subsubsection{Fourth Area: Learning \& Growth Process Perspective (Staff)}

Table 5. Mean and standard deviation of the paragraphs related to the area of "learning and growth"

\begin{tabular}{clcccc}
\hline No. & \multicolumn{1}{c}{ Paragraph } & Mean & Standard Deviation & Rank & Degree \\
\hline 1 & $\begin{array}{l}\text { The Bank raises the level of satisfaction to employees through applying incentives } \\
\text { and rewards systems. }\end{array}$ & 4.50 & 0.52 & 5 & High \\
2 & $\begin{array}{l}\text { The Bank provides training opportunities that are commensurate with the actual } \\
\text { needs of employees and the nature of their work. }\end{array}$ & 4.58 & 0.51 & 1 & High \\
& $\begin{array}{l}\text { The Bank promotes the culture of learning by sending employees to get the senior } \\
\text { academic degrees and professional certificates. }\end{array}$ & 4.58 & 0.51 & 1 & High \\
& $\begin{array}{l}\text { The Bank strengthens the work spirit of teamwork and activates communication } \\
\text { between the various departments and work centers. }\end{array}$ & 4.42 & 0.51 & 7 & High \\
\hline
\end{tabular}




\begin{tabular}{|c|c|c|c|c|c|}
\hline 5 & The bank applies replacement projects and career progressions in the bank. & 4.50 & 0.52 & 5 & High \\
\hline 6 & $\begin{array}{l}\text { The Bank attracts the best graduates of universities and attracts the scientific } \\
\text { qualification owners. }\end{array}$ & 4.58 & 0.51 & 1 & High \\
\hline 7 & $\begin{array}{l}\text { The Bank applies a self-service system for employees who can deal in which the } \\
\text { employee electronically with the Human Resources Department. }\end{array}$ & 4.42 & 0.51 & 7 & High \\
\hline 8 & $\begin{array}{l}\text { The Bank grants employees interest-free loans, which is reflected in the } \\
\text { organizational loyalty to the Bank. }\end{array}$ & 4.58 & 0.51 & 1 & High \\
\hline & "Learning and growth" as a whole & 4.52 & 0.19 & - & High \\
\hline
\end{tabular}

Note. Prepared by the researchers upon the results of a statistical analysis.

It is shown in the Table 5 that the arithmetic mean of the area paragraphs of "Learning and Growth" ranged between (4.42-4.58), the highest was for paragraph (2) which states that "The Bank provides training opportunities that are commensurate with the actual needs of employees and the nature of their work.", and the lowest paragraph is (7), which states that "The Bank applies a self-service system for employees who can deal in which the employee electronically with the Human Resources Department." with a mean of (4.42) and in a high degree, and the arithmetic means of the area of" Learning and Growth" reached as a whole (4.52) and in a high degree.

\section{Test Hypotheses}

\subsection{Test the First Hypothesis}

H01: There is no statistically significant difference at the significance level of $(\alpha \leq 0.05)$ for the arithmetic mean of the financial ratios with the average standard ratios for commercial banks sector.

Therefore, the financial ratios were extracted for the Housing Bank for Trade and Finance and Industry index ratios:

Table 6. Paired samples test

\begin{tabular}{|c|c|c|c|c|c|c|c|c|}
\hline & \multirow{2}{*}{ Mean } & \multirow{2}{*}{$\begin{array}{c}\text { Std. } \\
\text { Deviation }\end{array}$} & \multirow{2}{*}{ Std. Error Mean } & \multicolumn{2}{|c|}{ 95\% Confidence Interval of the Difference } & \multirow{2}{*}{$\mathrm{t}$} & \multirow{2}{*}{$\mathrm{df}$} & \multirow{2}{*}{ Sig. (2-tailed) } \\
\hline & & & & Lower & Upper & & & \\
\hline $\begin{array}{l}\text { Pair } 1 \\
\mathrm{x} 1-\mathrm{x} 2\end{array}$ & 7.6372 & 14.9884752 & 6.7030499 & -10.9734 & 26.2478 & 1.139 & 4 & .318 \\
\hline
\end{tabular}

Note. Prepared by the researchers upon the results of a statistical analysis.

By using (SPSS) program, (Paired Samples Test) analysis was used to test the moral difference between the calculated arithmetic means for the Housing Bank and the standard of the banking sector, we found through analysis that there is no difference between the arithmetic means with the standard and thus we accept the null hypothesis which view that there is no statistically significant difference at the level of significance of $(\alpha \leq 0.05)$ to the arithmetic mean of the financial ratios with the average standard ratios for commercial banks sector.

\subsection{Test the Second Hypothesis}

H02: There is a statistically significant low role at the level of significance of $(\alpha \leq 0.05)$ to use the customers' process on the performance of the Balanced Scorecard in the Housing Bank for Trade and Finance.

To test this hypothesis, "t" test was applied for (One-Sample t. Test) to detect Use customers' process (customer satisfaction) on the Housing Bank Balanced Scorecard at the Housing Bank for Trade and Finance, and the table (7) illustrates this.

Table 7. " $\mathrm{t}$ " Test results of (one-sample t. test) to detect use customers process (customer satisfaction) on the performance of the balanced scorecard in the housing bank for trade and finance

\begin{tabular}{lcccccc}
\hline & Mean & $\begin{array}{c}\text { Standard } \\
\text { Deviation }\end{array}$ & $\begin{array}{c}\text { Degree of } \\
\text { freedom }\end{array}$ & "t” Value & $\begin{array}{c}\text { Statistical } \\
\text { Significance }\end{array}$ & $\begin{array}{c}\text { Hypothesis } \\
\text { Result }\end{array}$ \\
\hline Customers (Customer Satisfaction) & 4.11 & 0.32 & 39 & 21.959 & 0.00 & Reject \\
\hline
\end{tabular}

Note. Prepared by the researchers upon the results of a statistical analysis.

The results showed the existence of a role for using customers' process (Customer Satisfaction) on the performance of the Balanced Scorecard in the Housing Bank for Trade and Finance; thus, the first hypothesis of the study is rejected and accepts the alternative hypothesis to become as follows: 
"There is a statistically significant role at the level of significance of $(\alpha \leq 0.05)$ to use the customers' process on the performance of the Balanced Scorecard in the Housing Bank for Trade and Finance".

\subsection{Test the Third Hypothesis}

H03: There is a statistically significant low role of the level of significance of $(\alpha \leq 0.05)$ to use the internal processes on the performance of the Balanced Scorecard in the Housing Bank for Trade and Finance.

To test this hypothesis, "t" test for (One-Sample t. Test) was applied to detect the use of the internal operations process of the Housing Bank Balanced Scorecard at the Housing Bank for Trade and Finance, and the table (8) illustrates this.

Table 8. " $\mathrm{t}$ " Test results of (one-sample t. test) to detect the use of the internal operations process on the performance of the balanced scorecard at the housing bank for trade and finance

\begin{tabular}{ccccccc}
\hline & Mean & $\begin{array}{c}\text { Standard } \\
\text { Deviation }\end{array}$ & $\begin{array}{c}\text { Degree of } \\
\text { freedom }\end{array}$ & $\begin{array}{c}\text { "t" Value } \\
\text { Significance }\end{array}$ & $\begin{array}{c}\text { Statistical } \\
\text { Result }\end{array}$ \\
\hline Internal processes & 4.47 & 0.26 & 11 & 19.435 & 0.00 & Reject \\
\hline
\end{tabular}

Note. Prepared by the researchers upon the results of a statistical analysis.

The results showed the existence of a role for using the internal processes on the performance of the Balanced Scorecard in the Housing Bank for Trade and Finance; thus, the first hypothesis of the study is rejected and accepts the alternative hypothesis to become as follows:

"There is a statistically significant role at the level of significance of $(\alpha \leq 0.05)$ to use the internal processes on the performance of the Balanced Scorecard in the Housing Bank for Trade and Finance".

\subsection{Test the Fourth Hypothesis}

H04: There is a statistically significant low role at the level of significance of $(\alpha \leq 0.05)$ to use the growth and learning process on the performance of the Balanced Scorecard in the Housing Bank for Trade and Finance.

To test this hypothesis, " $t$ " test for (One-Sample t. Test) was applied to detect the use of Growth and Learning process in Housing Bank Balanced Scorecard at the Housing Bank for Trade and Finance, and the table (9) illustrates this.

Table 9. Test results of (one-sample t. test) to detect using of growth and learning process on the performance of the balanced scorecard in the housing bank for trade and finance

\begin{tabular}{ccccccc}
\hline & Mean & $\begin{array}{c}\text { Standard } \\
\text { Deviation }\end{array}$ & $\begin{array}{c}\text { Degree of } \\
\text { freedom }\end{array}$ & "t" Value & $\begin{array}{c}\text { Statistical } \\
\text { Significance }\end{array}$ & Hypothesis Result \\
\hline Growth and Learning & 4.52 & 0.19 & 11 & 27.591 & 0.00 & Reject \\
\hline
\end{tabular}

Note. Prepared by the researchers upon the results of a statistical analysis.

The results showed the presence of a role for using the Growth and Learning process on the performance of the Balanced Scorecard in the Housing Bank for Trade and Finance; thus, the first hypothesis of the study is rejected and we accept the alternative hypothesis to become as follows:

"There is a statistically significant role at the level of significance of $(\alpha \leq 0.05)$ to use the Growth and Learning process on the performance of the Balanced Scorecard in Housing Bank for Trade and Finance".

\section{Results}

1) The study found that there is a role for Balanced Scorecard used at the Housing Bank for Trade and Finance on the performance:

2) There is no difference for the arithmetic mean of the financial ratios with the average standard ratios for commercial banks sector Thus, the Bank's financial performance is equal to the average performance of Jordanian commercial banks and thus the Housing Bank for Trade and Finance is characterized by a good financial performance.

3) There is a role for using the internal processes on the performance of the Balanced Scorecard in the Housing Bank for Trade and Finance Thus, the core of internal processes has been in line with the Bank's expectations.

4) There is a role of using Growth and Learning process on the performance of the Balanced Scorecard in the 
Housing Bank for Trade and Finance. Thus, the Bank aims, through its policy, to develop the level of employees by encouraging learning and growth

5) There is a role of using the customers' process on the performance of the Balanced Scorecard in the Housing Bank for Trade and Finance. Thus customer satisfaction was in line with the aspirations of the bank in serving its customers.

\section{Recommendations}

1) To continue using the Balanced Scorecard and adopts it contentiously, in order to reflect the strategic plans set by the bank for the purposes of achieving and sustaining it contentiously.

2) The need to maintain the degree of customer satisfaction achieved by the bank as it was high and came with the aspirations of the strategic bank.

3) Conducting further studies and researches on enhancing the role of balanced performance card as one of the modern management methods that contribute to enhancing performance.

4) The need to maintain the training process within the bank as it contributes to enhancing financial and nonfinancial performance.

\section{References}

Al-Natour, J. R. (2005). The impact of balanced scorecard standards used on investment decision in Jordanian industrial companies. Unpublished Master Thesis, Al al-Bayt University, Jordan.

Ardekani, S. S., Sharifabadi, A. M., Jalaly, M., \& Zarch, M. E. (2013). Comprehensive performance evaluation using FAHP-FVIKOR approach based on balanced scorecard (BSC): A case of Yazd's ceramic and tile industry. Iranian Journal of Management Studies, 6(2), 81.

Banker, R. D., Chang, H., \& Pizzini, M. J. (2004). The Balanced Scorecard Judgmental Effects of Performance. The Accounting Review, 79(1), 1-23. https://doi.org/10.2308/accr.2004.79.1.1

Braam, G. J. M., \& Nijssen, E. J. (2004). Performance effects of using the Balanced Scorecard: A note on the Dutch experience. Long Range Planning, 37(4), 335-349. https://doi.org/10.1016/j.lrp.2004.04.007

Dan, A. K. (2017). An Empirical Study on Balanced Scorecard as a Measurement and Management Tool for Corporate Performance. IUP Journal of Business Strategy, 14(4).

Daughtrey, A. S., \& Ricks, B. R. (1994). Contemporary supervision: Managing people and technology. McGraw-Hill Companies.

Davis, S., \& Albright, T. (2004). An investigation of the effect of Balanced Scorecard implementation of financial performance. Management Accounting Research, 15(2), 135-153. https://doi.org/10.1016/j.mar.2003.11.001

De Geuser, F., Mooraj, S., \& Oyon, D. (2009). Does the balanced scorecard add value? Empirical evidence on its effect on performance. European Accounting Review, 18(1), 93-122.

Duraid, K. A. (2007). Introduction to Contemporary Financial Management. Dar Al-Maseera.

Gesuele, B., \& Romanelli, M. (2015). Human Resource Measurement: A Balanced Scorecard Approach. Journal of Human Resource Management, 3(2-1), 28-32. https://doi: 10.11648/j.jhrm.s.2015030201.14

Gomes, R. C., \& Liddle, J. (2009). The balanced scorecard as a performance management tool for third sector organizations: The case of the Arthur Bernardes Foundation, Brazil. BAR-Brazilian Administration Review, 6(4), 354-366.

Housing Bank for Trade and Finance. (2014). Annual Report.

Humphreys, K. A., \& Trotman, K. T. (2011). The Balanced Scorecard: The Effect of Strategy Information on Performance Evaluation Judgments. Journal of Management Accounting Research, 23(1), 81-98. https://doi.org/10.2308/jmar-10085

Kaplan, R. S., \& Norton, D. P. (1996a). Using the balanced scorecard as a strategic management system. Harvard Business Review, January-February 1996a.

Kaplan, R. S., \& Norton, D. P. (1996b). The balanced scorecard: translating strategy into action. Harvard Business Press.

Kaplan, R. S., \& Norton, D. P. (2001). Transforming the Balanced Scorecard from Performance Measurement to Strategic Management: Part II. Accounting Horizons, 15(2), 147-160. 
Lucianetti, L. (2010). The impact of the strategy maps on balanced scorecard performance. Int. J. Business Performance Management, 12(1), 21-36. https://doi.org/10.1504/IJBPM.2010.036040

Michalska, J. (2005). The usage of The Balanced Scorecard for the estimation of the enterprise's effectiveness. Journal of materials processing technology, 162, 751-758. https://doi.org/10.1016/j.jmatprotec.2005.02.227

Mohammed, I. A. (2007). Using the balanced scorecard to evaluate performance in Kuwaiti industrial companies. Unpublished Master Thesis, Amman Arab University for Graduate Studies, Jordan.

Narayanamma, P. L., \& Lalitha, K. (2016). Balanced Scorecard - The Learning \& Growth Perspective. Aweshkar Research Journal, 21(2), 59-66.

Niven, P. R. (2005). Balanced scorecard diagnostics: Maintaining maximum performance. John Wiley \& Sons.

Niven, P. R. (2011). Balanced scorecard: Step-by-step for government and nonprofit agencies. John Wiley \& Sons.

Northcott, D., \& Ma'amora Taulapapa, T. (2012). Using the balanced scorecard to manage performance in public sector organizations: Issues and challenges. International Journal of Public Sector Management, 25(3), 166-191. https://doi.org/10.1108/09513551211224234

Noureddine, S. (2005). Activating the System of Evaluating Factor in the General Economic Institution. A thesis for a doctoral degree in Economic Sciences, University of Algiers.

Panicker, S., \& Seshadri, V. (2013). Devising a balanced scorecard to determine Standard Chartered Bank's Performance: A Case Study. International Journal of Business Research and Development, 2(2).

Pollanen, R. M., \& Xi, K. K. (2018). The effects of using balanced scorecard measures in executive compensation on organizational performance. International Journal of Business, Accounting, \& Finance, $12(1)$.

Sekaran, U., \& Bougie, R. (2016). Research methods for business: A skill building approach. John Wiley \& Sons.

Sleihat, N., \& Almahamid, S. (2013). The Impacts of Knowledge Management Practices on Balanced Score Card: An Empirical Investigation in Small-Medium-Size Manufacturing Companies. Jordan Journal of Business Administration, 9(1), 1-21.

Soderberg, M. (2006). The balanced scorecard: structure and use in Canadian companies. A Thesis submitted to the college of graduate studies and research, University of Saskatchewan.

The report of the Association of Banks for the year (2013).

\section{Websites}

http://en.wikipedia.org/wiki/Balanced_scorecard

http://www.hbtf.com/ar/

http://www.ase.com.jo/

http://www.abj.org.jo/ar-jo/home.aspx

\section{Copyrights}

Copyright for this article is retained by the author(s), with first publication rights granted to the journal.

This is an open-access article distributed under the terms and conditions of the Creative Commons Attribution license (http://creativecommons.org/licenses/by/4.0/). 